\title{
Costs of school transportation: quantifying the fiscal impacts of encouraging walking and bicycling for school travel
}

\author{
Noreen C. McDonald • Ruth L. Steiner • W. Mathew Palmer • \\ Allison N. Bullock • Virginia P. Sisiopiku • Benjamin F. Lytle
}

(C) Springer Science+Business Media New York 2014

\begin{abstract}
National governments have provided subsidies for investments in increasing the safety and attractiveness of walking and biking to school. Evaluations of Safe Routes to School initiatives have found that they have been effective at changing behavior and reducing injuries. However, there has been little attention to the impacts of these programs on pupil transportation costs. This analysis assesses the potential economic benefits of Safe Routes to School programs in the US context by estimating the annual costs of using motorized transport for short trips to schools, examining real-world examples of the costs savings of SRTS programs, and evaluating land use impacts on school transportation costs using a simulation analysis of school bus routes. We find that there is potential for school districts and families to reduce transport expenditures through public sector investments in walking and biking infrastructure near schools. We also find that land use context matters
\end{abstract}

N. C. McDonald $(\varangle)$. W. M. Palmer

Department of City and Regional Planning, University of North Carolina, New East Building,

CB 3140, Chapel Hill, NC, USA

e-mail: noreen@unc.edu

W. M. Palmer

e-mail: wmpalmer@email.unc.edu

R. L. Steiner - B. F. Lytle

Department of Urban and Regional Planning, University of Florida, Gainesville, FL, USA

e-mail: rsteiner@dcp.ufl.edu

B. F. Lytle

e-mail: ben.lytle@aecom.com

A. N. Bullock

Alta Planning + Design, Durham, NC, USA

e-mail: bullock.allison@gmail.com

V. P. Sisiopiku

Department of Civil, Construction, and Environmental Engineering, University of Alabama at Birmingham, Birmingham, AL, USA

e-mail: vsisiopi@uab.edu 
and the most cost-effective investments would benefit schools where large numbers of children live within walking distance.

Keywords School transport $\cdot$ Safe routes to school $\cdot$ Costs $\cdot$ School bus $\cdot$ Hazard busing

\section{Introduction}

Numerous studies have documented the positive economic impacts of investments in walking and bicycling infrastructure due to the health benefits of increased physical activity, improved safety, and decreased air pollution (Cavill et al. 2008; Jarrett et al. 2012). While these benefits have been studied across the population, there has been particular interest in the impacts on children and adolescents. In recent decades, levels of physical activity have decreased and obesity has increased among this group (Ogden et al. 2014). One policy response has been the introduction of Safe Routes to School (SRTS) programs that aim to increase walking and bicycling to school by making routes to school safer, providing education, and conducting encouragement programs. Currently such initiatives are found in Europe, New Zealand, Australia, Canada, and the United States. Researchers have looked at the impacts of these programs and found they lead to increased active travel and physical activity, and decreased injuries (DiMaggio and Li 2013; Stewart et al. 2014; Ragland et al. 2014; McDonald et al. 2014; Larouche et al. 2014).

Missing from the literature on the benefits of SRTS programs has been consideration of how these programs impact the public and private costs of getting students to and from school. This is a particularly important issue in the North American context where the public sector provides specialized school transport. American schools spent \$22.3 billion on student transportation expenses (or $4.2 \%$ of all education spending) during the 2010-2011 school year (U.S. Department of Education, National Center for Education Statistics 2013). However, the topic is also relevant outside North America where students often rely on public transit for school transport, a system which operates with public sector support. And across all countries, parents provide a substantial portion of school transport often by driving students to school.

This study uses mixed methods to assess the fiscal impacts of encouraging walking and bicycling for school travel. The focus is on understanding how improving pedestrian and bicycle infrastructure near schools could reduce the use of cars and buses for short trips to school. Reducing motorized transport could decrease public sector costs for busing students to school, private sector costs to families that drive their children to school, and related external costs of congestion and air quality. We assess these impacts through examination of real-world examples and a simulation analysis of school bus routing. The discussion assesses the spatial contexts where SRTS programs could generate the largest economic benefits and how economic benefits to districts and families relate to the costs of pedestrian and bicycle infrastructure.

This analysis is timely because recent cuts in education spending have disproportionately fallen on support services, such as transportation, in order to preserve classroom funding. Pupil transportation departments across the country have faced decreased budgets and increased fuel costs. This combination has led many districts to cut school bus service, potentially jeopardizing access to education for students. While this article focuses on the US context, these questions are transnational. Facing similar challenges, the UK and Australian governments are considering cutting subsidies for school travel (van Ristell et al. 2014; Cook 2012; Anonymous 2012). The current model of using motorized transport 
to overcome hazardous walking conditions may no longer be sustainable in the US or globally. This article highlights how SRTS can play a role in developing a new multimodal model of pupil transportation that promotes walking and biking for short trips and preserves school bus or public transit service for longer trips.

\section{School transportation costs background}

Getting children to school requires large expenditures by the public sector on school bus operations and infrastructure. But school transportation costs are not exclusively public. Nearly half of American students use private vehicles to reach school (McDonald et al. 2011). These families bear financial costs in terms of vehicle operation and time. Beyond the direct costs borne by public and private actors, school travel also imposes costs on society through externalities like vehicle emissions and congestion. These costs are justified by the enormous benefits to individuals and society of ensuring access to education for all children.

The remainder of this section provides an overview of public, private, and external school transportation costs in aggregate and for school trips of 1 mile or less. We highlight trips of 1 mile or less because walking and bicycling are viable modal substitutes for motorized transportation at these distances. National travel survey data show that fewer than $35 \%$ of students living within a mile from school walk or bike in the United States; the remainder of students use private automobiles $(44 \%)$ or ride the school bus (19\%) [authors' calculations using the 2009 National Household Travel Survey (Federal Highway Administration 2011)]. SRTS programs aim to change these travel patterns through education, encouragement, enforcement, and engineering strategies that make active modes safer and more attractive.

Public sector

In 2010-2011, student transportation expenses amounted to $\$ 22.3$ billion dollars in personnel and fuel costs U.S. Department of Education, National Center for Education Statistics (2013). The share of education expenditures for student transportation varied by state, from $2.4 \%$ in California to $7.3 \%$ in West Virginia. Transportation costs per enrolled student also varied widely across states. In Utah, the per-student cost of transportation was just $\$ 197$, well below the national average of $\$ 452$ (U.S. Department of Education, National Center for Education Statistics 2013). Other states with below average transportation costs per student included California (\$220), Texas (\$245), Oklahoma (\$243), and Colorado (\$250). Conversely, some states had high per pupil transportation costs far exceeding the national average. The District of Columbia had the highest per pupil cost in the nation at \$1,404 per student per year. New York (\$982), New Jersey (\$834), West Virginia (\$879), and Connecticut (\$803) also have higher than average per pupil transportation expenses.

However, state-level average per pupil transportation costs are not a strong metric of cost-effectiveness due to the variation in transportation policies and child density across states and school districts. Some of the observed cost differentials are caused by differing state rules around pupil transportation. California and Texas, for example, do not have state legislation that requires student busing (McDonald and Howlett 2007). New York not only requires transportation for students (for kindergarten through eighth grade students living more than 2 miles from school, and for ninth through twelfth grade students living more than 3 miles from school), but also reimburses a large proportion of those costs. Some 
states, such as California, have lower average costs simply because they are transporting a smaller proportion of students. Conversely, rural states and school districts may transport children longer distances because of the dispersed nature of population settlement, which increases costs. In addition, some pupil transportation costs are mandated by the federal government and cannot be voluntarily reduced by school districts. Busing is federally required for all homeless students and students with documented special needs. While national data on special needs busing is scarce, a 2002 study by the Center for Special Education Finance estimates that special needs busing costs account for $28 \%$ of total pupil transportation expenditures nationwide (Chambers et al. 2002).

\section{Hazard busing}

Most districts provide school bus service when students live more than a specified minimum distance from school, generally 1-2 miles. However, many districts bus children to school if the walking conditions are unsafe even when they do not meet the distance threshold; this is known as "hazard busing." According to Chriqui et al. (2012), just under a third of states allow exemptions to the minimum distance requirements when hazardous walking conditions exist and other states allow informal exemptions. Little is known about hazard busing rates nationwide, but the provision of busing for short distances creates policy challenges. In 2009, American families reported that $5.6 \%$ of elementary and middle school students lived within 1 mile of school and used a school bus (authors' calculations using the 2009 National Household Travel Survey). Presumably, a large portion of these students received hazard busing, though that was not asked in the survey. Florida provides detailed annual estimates of hazard busing. In the 2011-2012 school year, $1 \%$ of all students in Florida received hazard busing; this equated to $4 \%$ of all students riding the bus (Florida Department of Education 2013). However, there is great variation across school districts. In Hillsborough County, which includes Tampa, $6 \%$ of all students are bused due to hazardous walking conditions. In Escambia County, which includes Pensacola, $12 \%$ of students receive hazard busing (Florida Department of Education 2013).

Estimating the costs of providing school bus service to students living within a walkable distance of their school is difficult given uncertainties in prevalence. However, the available US data suggest that approximately one to five percent of students receive hazard busing. This equates to 0.5-2.5 million American students who receive hazard busing. Per student costs for hazard busing are likely less than the US average per-student transportation cost of $\$ 452$ because that figure includes students with special needs and those that live quite far from school. If we assume that hazard busing costs are substantially less because of the short distances involved (approximately $\$ 200$ per student) then the annual cost of hazard busing is between $\$ 100$ and $\$ 500$ million across the United States.

\section{Private costs}

Over half of American students reach school by private vehicle (McDonald et al. 2011). Parents drive children for many reasons including convenience, time savings, concerns about traffic safety and stranger danger, or a lack of other options if the school does not provide busing (McDonald and Aalborg 2009; Dellinger and Staunton 2002; Zhu and Lee 2009). In high school, many teens drive themselves and, in some cases, classmates to school. McDonald et al. (2011) found that auto trips to and from school accounted for 30 billion vehicle miles and 6.6 billion vehicle trips in 2009. Of these trips, $40 \%$ were 
undertaken specifically to drop a child at school and then return home (McDonald et al. 2011). The American Automobile Association (AAA) estimates the cost of gas, maintenance, and tires at 20 cents per mile (American Automobile Association 2013). Based on these estimates, auto trips to and from school cost a minimum of $\$ 2$ billion if we only consider cases where parents made a special trip or a maximum of $\$ 6$ billion if we consider all private vehicle school mileage.

The estimates above ignore the value of travelers' time. We know of no research that has investigated the value of parents' time while chauffeuring children to school. There is anecdotal evidence that some parents place positive value on driving children to and from school because of the opportunity to spend time with their children; for others, it may impose costs because of decreased time available for paid employment. The US Department of Transportation provides general guidance on the value of travel time and suggests that time spent traveling should be valued at 35-60\% of after-tax hourly wages $(\$ 8.40$ \$14.40) for local, personal travel (Trottenberg 2011). Using the low end (35\%) of the Department of Transportation range and assuming travel speeds average $30 \mathrm{mph}$, we found that the time costs of parents' driving children to school are around $\$ 3$ billion for special trips to drop children at school and $\$ 8$ billion for all school-related mileage.

Private vehicle costs of short school trips

In 2009, $44 \%$ of the 10 million elementary and middle school students living within 1 mile of school were driven to school (National Center for Education Statistics 2012; Federal Highway Administration 2014). We estimate that the costs to the private sector of these short-distance trips were approximately $\$ 720$ million or $4.5 \%$ of the estimated aggregate costs of driving children to school. These costs reflect the vehicle operating expenses and value of parent travel time for short trips where a parent made a special trip to bring their child to school. While many parents drop children on their way to work, approximately $40 \%$ make special trips to bring children to school (McDonald et al. 2011). Assuming an average one-way trip distance of a half-mile for these students and vehicle occupancy of 1.5 children, we estimate that driving K-8 students living within 1 mile of school generates 1.5 billion excess vehicle miles of travel annually. Assuming vehicle operation costs of 20 cents per mile (American Automobile Association 2013), this equates to $\$ 300$ million in private vehicle expenses. If we include the value of time in these estimates, the costs of parents driving children to school increase substantially. If those 1.5 billion excess vehicle miles represent approximately 50 million excess hours of travel (assuming a rather fast average travel speed of $30 \mathrm{mph}$ ), then the collective value of the travel time is $\$ 420$ million when the value of time is $35 \%$ of the average hourly wage rate.

\section{External costs}

Travel generates other costs which are not necessarily borne by the public or private sectors. These externalities include the adverse health impacts of vehicle emissions, the climate impacts of greenhouse gas emissions, and the time costs imposed on other road users due to congestion. Schools have been identified as major trip generators (McMillan 2007). During the school year, up to $25 \%$ of morning traffic on local roads and 5-7\% of vehicle miles traveled are generated by parents driving their children to school (McDonald et al. 2011; Parisi Associates n.d.). According to the Federal Highway Administration, estimates of the monetary costs of congestion delays range from $\$ 0.01$ to $\$ 0.09$ per vehicle mile traveled. For local air pollution damage, the cost estimates for an average car range 
from $\$ 0.01$ to $\$ 0.07$ per vehicle mile traveled and from $\$ 0.01$ to $\$ 0.21$ per vehicle mile traveled by diesel bus. For greenhouse gas control and damage costs, the estimates for an average car range from $\$ 0.02$ to $\$ 0.21$ per vehicle mile traveled and from $\$ 0.84$ to $\$ 1.03$ per vehicle mile traveled by diesel bus (Litman and Doherty 2009; Federal Highway Administration 1997). Considering vehicle mile traveled (VMT) only related to special purpose school trips, this would cost approximately $\$ 120$ million for congestion, $\$ 120$ million for air pollution, and $\$ 240$ million for greenhouse gas impacts.

\section{External costs for trips of 1 mile or less}

Above we estimated that driving children to school a distance of less than 1 mile generated 1.5 billion excess private vehicle miles of travel annually. Using the low end of the cost range for these externalities, we find that driving children to school for short trips generates at least $\$ 15$ million in congestion costs, $\$ 15$ million in air pollution costs, and $\$ 30$ million in greenhouse gas costs annually. We are unable to estimate costs associated with excess school bus trips because we lack information about how hazard busing affects school bus VMT nationally.

\section{Summary}

In total, annual expenditures on school transportation operating expenses for motorized modes are approximately $\$ 30$ billion for school districts and families (Table 1). We estimate that the proportion of those expenses related to transporting students short distances (defined as less than 1 mile) are approximately $\$ 0.9$ to $\$ 1.3$ billion or 3-5\% of total public and private sector costs. Externalities from private vehicle school trips, such as traffic congestion near schools and the air quality impacts of additional driving, add to this cost, though those expenses are difficult to estimate.

\section{Impacts of safe routes to school programs on school transportation costs: methodology}

We used mixed methods to assess the economic impacts of SRTS. First, we documented real-world examples of SRTS improvements leading to cost savings for school districts and families. To identify these examples, we reviewed the literature and contacted each state's designated Safe Routes to School State Coordinator and technical assistance staff from the Safe Routes to School National Partnership. Of the 51 state coordinators contacted, 21 (42\%) responded. A small number of respondents provided examples of SRTS investments that had resulted in reduced school bus or private vehicle costs. For each of the identified examples, we reached out to local contacts and conducted open-ended interviews through email or phone to gather information about the impacts of SRTS on busing and driving to school. From this process, we identified four case studies in Highland Park, NJ; Columbia, MO; Phoenix, AZ; and Austin, TX. The literature also contained examples from Auburn, WA; Marin County, CA; Eugene, OR; and Wooster, OH. Our examination focused on the connections between SRTS improvements and public and private sector costs; we did not focus on the factors that led to successful implementation of the SRTS program since other publications have addressed this topic (see for example National Center for SRTS 2012). 
Table 1 Summary of the costs associated with motorized school transportation: all trips and trips less than 1 mile

\begin{tabular}{ll}
$\begin{array}{l}\text { Total costs- } \\
\text { all distances }(\$ \text { million })\end{array}$ & $\begin{array}{l}\text { Costs- trips } \leq \\
1 \text { mile }(\$ \text { million })\end{array}$ \\
\hline
\end{tabular}

Public sector

School districts

$100-500$

Private sector

Private vehicle operating costs

$2,000-6,000^{\mathrm{a}}$

300

Value of parents' travel time

$3,000-8,000^{\mathrm{a}}$

Externalities

Traffic congestion near schools from autos

$120-300^{\mathrm{a}}$

Not estimated

360-900

Not estimated
15

Not estimated 45

Not estimated

Air pollution and greenhouse gases from school buses

a The low end considers only trips made solely to chauffeur a child to school; the high end considers all school-related VMT including trips where parents dropped children on their way to another destination

Second, we used simulation analysis to estimate how busing children short distances impacted the overall efficiency and costs of school bus service and to understand how these impacts varied with local context, particularly child density and average distance between home and school. For example, a SRTS program at a school where all students lived within walking distance could come close to eliminating motorized transport costs. Conversely, SRTS improvements would not decrease busing costs if no students lived within walking and biking distance of the school. We then assessed the savings in school bus costs that would result from getting students who lived near school to walk and bike. These costs savings were then compared to the costs of SRTS improvements.

We utilized school bus routing software to simulate the potential impacts of SRTS programs on busing costs. As a case study, we selected four elementary schools from a large North Carolina public school district for the analysis; magnet schools were excluded. The schools were selected to ensure variation in the number of students living near school. School A with $92 \%$ of students living within 1 mile was located in an urban part of the district (Table 2). School D, where only $22 \%$ of students lived within 1 mile of the school, was located in a suburban/exurban area, where the development patterns were characterized by loop- and lollipop-type residential subdivisions. The remainder of the schools varied between those two extremes.

To estimate how a SRTS program could impact busing costs by reducing the need for hazard busing, we analyzed three scenarios for each school (Table 3). These scenarios varied in the proportion of students living near the school that were bused. Under scenario 1 (no hazard busing), no students living within 1 mile of the school were assigned to bus routes. For scenario 2, we assumed that half the students living within 1 mile of school received hazard busing; students were selected at random. The final scenario assumed that all students living within 1 mile of school required hazard busing. For each of the three scenarios, students living outside walking distance, i.e. 1 mile, were included in the analysis, but their assignment (bus/no bus) never changed and was based on what the students had elected. For each scenario and school, the Pupil Transportation Group at North Carolina State University used Education Logistics (EDULOG) software to calculate school bus vehicle miles traveled (VMT), the number of buses used, and the number of students 
Table 2 Characteristics of schools in simulation analysis

\begin{tabular}{lllll}
\hline & $\begin{array}{l}\text { Students living } \\
\text { within 1 mile }(\%)\end{array}$ & $\begin{array}{l}\text { \# of } \\
\text { students }\end{array}$ & $\begin{array}{l}\text { Average travel } \\
\text { distance to } \\
\text { school (miles) }\end{array}$ & $\begin{array}{l}\text { Development } \\
\text { pattern near school }\end{array}$ \\
\hline School A & 92 & 385 & 0.8 & Gridded streets \\
School B & 74 & 604 & 0.8 & Gridded streets \\
School C & 62 & 264 & 1.4 & Gridded streets \\
School D & 22 & 460 & 2.5 & Loop and lollipop \\
\hline
\end{tabular}

Table 3 School busing simulation scenarios

\begin{tabular}{|c|c|c|c|}
\hline Student residence & $\begin{array}{l}\text { Scenario } 1 \\
\text { no hazard busing }\end{array}$ & $\begin{array}{l}\text { Scenario } 2 \\
\text { half hazard busing }\end{array}$ & $\begin{array}{l}\text { Scenario } 3 \\
\text { all hazard busing }\end{array}$ \\
\hline Within 1 mile of school & None bused & $\begin{array}{l}50 \% \text { of students bused (selected at } \\
\text { random) }\end{array}$ & $\begin{array}{l}100 \% \text { of students } \\
\text { bused }\end{array}$ \\
\hline $\begin{array}{l}\text { More than } 1 \text { mile from } \\
\text { school }\end{array}$ & $\begin{array}{l}\text { Current ridership } \\
\text { status }\end{array}$ & Current ridership status & $\begin{array}{l}\text { Current ridership } \\
\text { status }\end{array}$ \\
\hline
\end{tabular}

serviced. For input parameters, such as maximum trip length, arrival times, and bus stop locations, we utilized state or district standards. We did not attempt to estimate how changes in hazard busing would impact private sector costs.

The estimates of bus route VMT and number of buses were then used to estimate the costs to the school district to provide school bus service of each scenario. The two components of variable school district transport costs are capital expenditures (the money required to purchase buses) and operations and maintenance. We assumed the district utilized a two-tiered school transport structure where one bus can service two schools in the morning and afternoon due to staggered bell times. In practice, this means that capital and operating expenses associated with the school bus are divided by two to account for the fact that one school bus serves two routes. For capital costs, we estimated annual costs per school bus by amortizing the school bus purchase costs of $\$ 86,500$ over an anticipated 20 year lifespan at a social discount rate of 3.5\% (Delucchi 2005, pp. 3-4; Moore et al. 2004). Based on these calculations, we estimated that each additional bus route required $\$ 3,043$ annually in capital costs (i.e. half of the amortized cost per school bus) (Table 4). Annual expenses for operating and maintaining the school transportation network include $\$ 0.49$ per daily school bus vehicle mile for fuel, $\$ 7.42$ in insurance costs per student bused, and $\$ 14,216$ per school bus route for vehicle maintenance, driver and mechanic pay, and safety monitoring (Table 4). These costs were derived from an investigation of school transportation costs in North Carolina and reported values from the literature (Sisiopiku et al. 2013).

\section{Results}

The following sections present the results of our mixed-methods investigations of the potential for non-infrastructure investments to reduce school transportation costs, particularly to the public sector. The first section documents real-world examples of school 
Table 4 Estimated public sector costs of providing school bus service

\begin{tabular}{lccc}
\hline & Per school bus route ${ }^{\mathrm{a}}$ & $\begin{array}{l}\text { Per daily bus } \\
\text { VMT }\end{array}$ & $\begin{array}{l}\text { Per student } \\
\text { bused }\end{array}$ \\
\hline $\begin{array}{l}\text { Annualized school bus capital costs } \\
\text { Operating costs }\end{array}$ & 3,043 & 0 & 0 \\
Insurance & 0 & 0 & 7.42 \\
Fuel & 0 & 0.49 & 0 \\
Bus driver & 6,813 & 0 & 0 \\
Vehicle maintenance & 7,265 & 0 & 0 \\
Detection and surveillance (including GPS) & 138 & 0 & 0 \\
Total operating expenses & 14,216 & 0.49 & 7.42 \\
Total capital + operating & 17,259 & 0.49 & 7.42 \\
\hline
\end{tabular}

a Assumes two-tiered bus routes

districts that reduced costs to the school district and families through SRTS programs. The second section reports on the school bus routing simulation analysis that assessed whether reductions in hazard busing could reduce school district transportation expenses.

\section{Results: real-world examples of the economic impacts of SRTS investments}

Through interviews with SRTS experts and the literature, we identified five examples where investments in SRTS reduced busing costs and three examples of reduced private vehicle costs.

Public costs: reduced school busing service

Starting in fall 2008, the Highland Park, New Jersey school district eliminated school bus service in response to a significant reduction in state funding and saved $\$ 100,000$ per year in transportation costs. Cutting school bus service was possible because the town is small $\left(1.9\right.$ miles $\left.^{2}\right)$ and nearly all residents live within 2 miles of school. In anticipation of the impact that busing cuts would have on the 110 students affected, the School Board and community partners implemented SRTS initiatives to improve safety. Schools designated walk-to-school routes and schools and parents organized Walking School Buses. Crossing guards were hired to assist with larger intersections along the walking routes. To encourage active transportation to school in lieu of driving, all four public schools also installed more bike racks and permitted students to store scooters, skateboards, roller skates, and other transportation equipment in the school office if they did not fit in lockers. Since 2008, Highland Park has also installed new sidewalks; raised and repainted crosswalks at key intersections and transit stops; and implemented traffic calming measures, such as curb extensions and pedestrian islands, to further improve the safety of walking and bicycling.

SRTS programs have also been used to reduce transportation costs by increasing the efficiency of bus routes. In June 2013, a Walking Bus Stop pilot program was launched for Russell Elementary School (Columbia, Missouri) to encourage children to walk together to a neighborhood school bus stop. Rather than having the school bus pick up and drop off children separately at their respective residences, the school bus stops for one 
neighborhood were consolidated into a single stop. Volunteer walk leaders led a walking group along a $3 / 4$-mile route to and from the school bus each day, picking up children at their residences along the way. The program showed that consolidating bus stops saved the district fuel, bus wear-and-tear, and $10 \mathrm{~min}$ of driver time for each bus trip to or from school. While this pilot program was implemented at a small scale with one neighborhood along one school bus route, the program demonstrated the ability for significant pupil transportation cost savings if scaled up to multiple neighborhoods per route along the more than 100 school bus routes that serve Columbia Public Schools.

In Auburn, Washington, investments in signage, sidewalks, paths, and traffic calming measures around schools improved the safety of local routes to school and reduced the need for hazard bus service. These interventions, coupled with SRTS-funded sidewalks and bike lanes, made it possible for $20 \%$ of students in Auburn to walk or bike to school, saving the city $\$ 240,000$ every year in hazard busing costs (Safe Routes to School National Partnership 2010). At one Auburn elementary school, the interventions resulted in $85 \%$ of children walking or biking to school and allowed bus service to be reduced from six buses to one (Pullen-Seufert et al. 2009). Melrose Elementary in Wooster, Ohio similarly reduced hazard busing service in exchange for SRTS-funded sidewalks, crosswalks, and school zone signage (Pedroso et al. 2011). The reduced need for hazard busing saved the school district $\$ 49,000$ per year. These cases demonstrate how Safe Routes to School investments can help school districts reduce pupil transportation costs and plan for tighter transportation budgets by creating safe walking and bicycling alternatives to school.

In 2014, the city of Austin constructed a pedestrian bridge over a creek to connect apartments serving low-income families with their elementary school located a half-mile away. The bridge cost $\$ 750,000$ and was paid for by the City and federal grants. Prior to bridge construction, students were bused to school because there was no safe walking route. Because of the street configuration, school bus routes were at least 3 miles each way. With the bridge in place, the school eliminated several bus routes, saving $\$ 130,000$ in annual busing costs. City and school officials also coordinated construction of the bridge with outreach efforts to teach students about safe walking and biking and provide students the opportunity to receive a free bicycle and training on bike safety in coordination with the City and the Police Department.

The Austin example highlighted two critical factors: coordination between the City and the school district and recognizing child safety as an important factor in deciding where to make pedestrian and bicycle improvements. In Austin, the Public Works department has a Child Safety program. This program receives funding from fees for vehicle registration, parking violations, and traffic violations that occur in a school zone and is responsible for pedestrian and bicycle safety education in the schools and for school crossing guards. Staff from the Child Safety Program work closely with school district pupil transportation staff to monitor school travel safety and identify opportunities to remove hazards. Because the Child Safety Program is located in the Public Works department, they are also uniquely able to address the need for improved child pedestrian safety in City of Austin Public Works projects.

Private costs: reduced passenger vehicle driving

Existing research shows that SRTS interventions have been successful in reducing motor vehicle trips to schools and the associated cost of that travel. A study on the Marin County SRTS program examined pre- and post-intervention walking and biking rates to school after implementing education and encouragement investments that included classroom 
education, walking and biking days, mapped routes, walking trains, and school newsletters. From 2000 to 2002, the number of children walking to school increased by $64 \%$; the number of students biking increased by $114 \%$; the number of students carpooling increased by $91 \%$; and the number of motor vehicles carrying one student decreased by $39 \%$ (Staunton et al. 2003). Similar results were seen at Roosevelt Middle School in Eugene, Oregon, where a combination of infrastructure and non-infrastructure SRTS investments were made in crosswalks, school zone signage, a pedestrian path, and education and encouragement programs. The proportion of students walking and biking to school subsequently increased over a three-year period from $27 \%$ in 2007 to $42 \%$ in 2010. At the same time, the number of cars picking up children from school decreased by $24 \%$ (Pedroso et al. 2011).

Since starting its Safe Routes to School program, Eagle College Preparatory in Phoenix, Arizona, has seen considerable increases in children walking and biking to school and reductions in family car trips. In 2010, just one percent of students walked to school. As of 2013 , the proportion of children walking to school has increased to $12 \%$. At the same time, the drop-off and pick-up process for students who are driven to and from school has been streamlined. With more students walking and biking, the time it takes to unload and load students before and after school has been reduced by half. These improvements reduced the amount of time monitors are needed to supervise student loading zones, the number of cars idling and the length of time idling, and resulting emissions.

\section{Results: analysis of school bus network impacts of SRTS programs}

The busing simulation analysis performed in this study assessed how the amount of hazard busing combined with the local land use context influenced the costs of providing school bus service. At school A, with $92 \%$ of students living within 1 mile, we found only one school bus was required with no hazard busing. However, providing hazard busing to all students living within 1 mile would require four additional buses (Table 5). The impact of hazard busing depended on the geographic context of the school. School D, located in a more suburban area where only $22 \%$ of students lived within 1 mile, required five buses in the base case of no hazard busing, but only two additional buses if all children living within 1 mile of the school were bused.

The simulation suggested that the cost impacts of hazard busing can be significant. At School A, busing the 29 students who lived more than 1 mile from school would cost $\$ 60$ per enrolled student per year. Per student costs increased substantially with hazard busing. Providing hazard busing to half of students living within 1 mile of School A would cost

Table 5 Number of students bused, bus vehicle miles of travel, and number of buses for all schools and scenarios

\begin{tabular}{|c|c|c|c|c|c|c|c|c|c|}
\hline \multirow{2}{*}{$\begin{array}{l}\text { Hazard busing } \\
\text { (HB) }\end{array}$} & \multicolumn{3}{|c|}{ \# Students bused } & \multicolumn{3}{|c|}{ Bus VMT } & \multicolumn{3}{|c|}{ \# of buses } \\
\hline & $\begin{array}{l}0 \% \\
\mathrm{HB}\end{array}$ & $\begin{array}{l}50 \% \\
\mathrm{HB}\end{array}$ & $\begin{array}{l}100 \% \\
\mathrm{HB}\end{array}$ & $\begin{array}{l}0 \% \\
\mathrm{HB}\end{array}$ & $\begin{array}{l}50 \% \\
\mathrm{HB}\end{array}$ & $\begin{array}{l}100 \% \\
\mathrm{HB}\end{array}$ & $\begin{array}{l}0 \% \\
\mathrm{HB}\end{array}$ & $\begin{array}{l}50 \% \\
\mathrm{HB}\end{array}$ & $\begin{array}{l}100 \% \\
\mathrm{HB}\end{array}$ \\
\hline School A & 29 & 206 & 384 & 49 & 91 & 100 & 1 & 3 & 5 \\
\hline School B & 155 & 379 & 603 & 103 & 122 & 181 & 3 & 6 & 10 \\
\hline School C & 97 & 180 & 263 & 148 & 160 & 150 & 2 & 4 & 4 \\
\hline School D & 354 & 406 & 459 & 212 & 290 & 294 & 5 & 6 & 7 \\
\hline
\end{tabular}



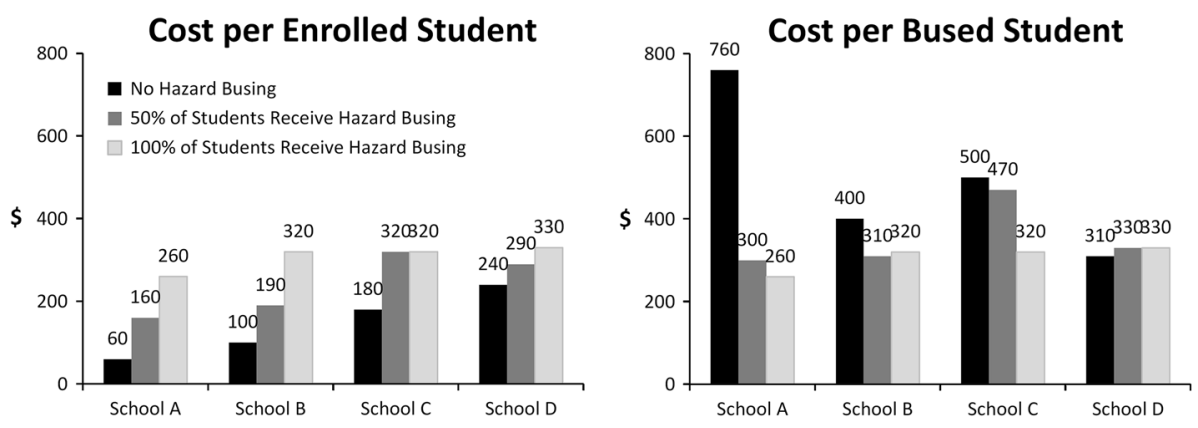

Fig. 1 School bus transportation costs by hazard busing scenario: per enrolled student and per bused student

$\$ 160$ per enrolled student per year-an increase of $\$ 100$ over the base case of no hazard busing (Fig. 1). Busing all students living within 1 mile would cost $\$ 260$ per enrolled student per year. The magnitude of the per-student cost increase due to hazard busing decreased as fewer students lived within 1 mile. At School D, providing all students living within 1 mile with hazard busing cost $38 \%$ more on a per-student basis than the base case of no hazard busing. These results suggested that reducing the need for hazard busing through infrastructure improvements could lead to cost savings. Investments in pedestrian and bicycle infrastructure would be most effective at reducing costs at schools with high amounts of hazard busing and large numbers of children that live within walking distance of school.

Providing hazard busing consistently led to an increase in aggregate and per enrolled student school bus expenses. However, some districts and states evaluate the efficiency of school bus provision by considering costs per bused student. For example, the cost per enrolled student (and therefore total costs) at School A was minimized when no hazard busing was provided. However, the cost per bused student at School A was $\$ 760$ with no hazard busing but dropped to $\$ 260$ when all students living near school received hazard busing (Fig. 1). The latter is clearly more costly overall, but assessing costs per bused student can obscure this fact. This point is not unimportant. Some states, such as North Carolina, reimburse districts based on the efficiency of their school transportation and this may provide an incentive to bus students living near school in order to minimize costs per bused student (Safe Routes to School National Partnership 2014).

\section{Value of cost savings}

Cost savings from eliminating hazard busing represent permanent cost savings to school districts. As such, it is appropriate to capitalize the savings over time. Over a relatively modest ten year period, eliminating hazard busing at School $\mathrm{A}$ is worth $\$ 860$ per enrolled student if half of students are hazard bused (at a social discount rate of $3.5 \%$ ) (Table 6). For a 385 student school, this represents $\$ 330,000$. Potential cost savings are lowest at the least-dense school, School D, due to residential location patterns that require substantially more busing and the smaller number of students living close to the school.

These cost savings compare favorably with the costs of improving infrastructure to eliminate the need for hazard busing. Table 7 details the costs of common SRTS improvements and makes clear that, in many contexts, an economic argument can be made 
Table 6 Value of eliminating hazard busing

\begin{tabular}{llcrl}
\hline School & Enrollment & Annual cost savings & \multicolumn{2}{l}{ Net present value over 10 years } \\
\cline { 4 - 5 } & & Per-student & Per-student & Per-school \\
\hline School A & 385 & $\$ 100$ & $\$ 860$ & $\$ 330,000$ \\
School B & 604 & $\$ 90$ & $\$ 760$ & $\$ 459,000$ \\
School C & 264 & $\$ 140$ & $\$ 1,140$ & $\$ 301,000$ \\
School D & 460 & $\$ 50$ & $\$ 450$ & $\$ 206,000$ \\
\hline
\end{tabular}

Based on eliminating hazard busing to $50 \%$ of students living within 1 mile

Table 7 Estimated cost of common SRTS infrastructure improvements
Source Bushell et al. (2013, Appendix D)

\begin{tabular}{lcl}
\hline Item & Cost (median) & Unit \\
\hline Bicycle rack & 540 & Each \\
Bicycle lane & 89,470 & Mile \\
High visibility crosswalk & 3,070 & Each \\
Striped crosswalk & 340 & Each \\
Rapid flashing beacon & 14,160 & Each \\
Median island & 10,460 & Each \\
Multi-use trail-paved & 261,000 & Mile \\
School crossing & 520 & Each \\
Concrete sidewalk & 27 & Linear foot \\
Crossing Guard & 6,360 & Intersection \\
\hline
\end{tabular}

for decreasing busing costs by making infrastructure improvements near schools. For example, if a dangerous road crossing prevents students from walking to school, the crossing could be improved with the addition of a high-visibility crosswalk, flashing beacon, and median island. The costs of these improvements are often substantially less than the present value of the costs of busing students over a ten-year period.

\section{Discussion}

School busing was introduced to allow students living far from schools to receive an education. However, as concerns about traffic safety and stranger danger have increased, the majority of children living within walking distance are now transported by bus or private vehicle. Leaving aside potential health benefits from increased walking and biking, the analysis presented in this paper suggests there are opportunities for cost savings for state departments of education, local school districts, families, and communities if these trends reverse. Schools can save money by eliminating hazardous conditions that make it difficult for many students to walk short distances to school. Families can eliminate the costs associated with private travel by walking or biking their children to school or collaborating with neighbors to ensure the safe movement of their children to school. Communities can save through reduced congestion near schools and the costs associated with exposure to air pollution. 
The elimination of hazard busing through infrastructure investment can reduce the pupil transportation costs by an estimated \$100-\$500 million per year. If these children then walk or bicycle to school, these cost savings can be fully realized. If parents drive their children to school when hazard busing is eliminated, this will reduce costs to schools but have the unfortunate effect of increasing costs for families. Several school districts have used SRTS investments to eliminate hazard busing or address cuts in school busing through improved infrastructure. Austin, Texas provides a compelling example of how cities and school transportation departments can work toward a common goal of providing safe travel for children across multiple modes. This analysis also shows that the economic returns of SRTS investments are highest at schools where many students live within walking distance and could benefit from SRTS projects.

The difficulties associated with the argument that SRTS investments can save money by eliminating hazard busing are multidimensional and complicated by current institutional practices. In the United States, infrastructure improvements are generally the responsibility of the municipality or the state department of transportation. When school districts provide school bus service, the costs are borne locally and may be partially offset through reimbursements from the state department of education. So the costs and benefits of reducing hazard busing accrue to different agencies. Overcoming these barriers requires agreement between the city, schools, and parents that safe school travel requires busing for students living beyond a walkable distance and safe streets for students living close to school. Beyond the shared vision, cities and schools must also work together so that cities are aware of the need for infrastructure improvements and schools have advance warning about improvements.

State departments of education must also consider how pupil transportation assistance to districts encourages or discourages walking and bicycling. Our analysis highlighted how some reimbursement formulas that focus on costs per bused student might actually encourage inefficient busing practices among school districts. In order to reduce perstudent cost calculations, districts may provide busing to students living near schools who might otherwise walk, thereby encouraging inefficient use of public resources. Simple fixes, such as including language that eliminates reimbursement for students living within walking distance, would remove this incentive and encourage school districts to work with municipal governments to eliminate hazardous walking conditions near schools.

Finally, the removal of hazard busing due to the elimination of dangerous conditions can only be considered fully successful if families utilize the infrastructure and children begin to walk and bike. If the removal of hazard busing simply shifts the costs of getting students to school onto families, then there is little benefit to society. Thus, schools and cities working together to identify and mitigate hazardous conditions is not enough; families must be part of the process as well. Cutting hazard bus routes-even if conditions no longer warrant them-can feel like cutting a public service to families. Unless the city and district communicate the proposed changes and provide extra services, such as crossing guards, to aid in the transition, families may not like the change and may even oppose implementation.

Further research related to the potential fiscal benefits of non-motorized infrastructure improvements is needed. Within the realm of children's travel, there is need for detailed analyses that calculate the changes in transportation costs resulting from SRTS investments. Studies analyzing the impacts of SRTS should begin to include economic factors and not only safety and travel behavior. Broader evaluations of the co-benefits of walking and bicycling should also consider the inclusion of fiscal dimensions, particularly related to public sector costs. 


\section{Conclusion}

SRTS programs have been shown to be effective at increasing walking and bicycling, physical activity and safety. Most previous evaluations have focused on these metrics and their attendant health benefits. However, this paper has demonstrated that SRTS programs could also provide economic benefits by reducing the need to bus or drive students to overcome hazardous walking conditions. Opportunities for cost savings will vary with the local context. Investments in SRTS infrastructure will provide the largest financial benefit in situations where a large proportion of students live near the school and many of these students receive hazardous busing. While these results derive from the US context, the lessons apply whenever the public and private sectors pay for motorized transport to overcome hazardous walking conditions.

Acknowledgments This project was funded by the Active Living Research program of the Robert Wood Johnson Foundation and the Southeastern Transportation Research, Innovation, Development and Education Center (STRIDE) with funding from US Department of Transportation.

\section{References}

American Automobile Association: Your driving costs: how much are you really paying to drive? American Automobile Association, Washington, DC (2013)

Anonymous: Vic school transport subsidy cuts attacked. The Australian. (2012) http://www.theaustralian. com.au/news/latest-news/vic-school-transport-subsidy-cuts-attacked/story-fn3dxiwe-1226526055643

Bushell, M.A., Poole, B.W., Zegeer, C.V., Rodriguez, D.A.: Costs for pedestrian and bicyclist infrastructure improvements: a resource for researchers, engineers, planners and the general public. UNC Highway Safety Research Center, Chapel Hill, NC (2013)

Cavill, N., Kahlmeier, S., Rutter, H., Racioppi, F., Oja, P.: Economic analyses of transport infrastructure and policies including health effects related to cycling and walking: a systematic review. Transp. Policy 15, 291-304 (2008). doi:10.1016/j.tranpol.2008.11.001

Chambers, J.G., Parrish, T.B., Lam, I.: What are we spending on transportation services for students with disabilities, 1999-2000? Center for Special Education Finance, Palo Alto, CA (2002)

Chriqui, J.F., Taber, D.R., Slater, S.J., Turner, L., Lowrey, K.M., Chaloupka, F.J.: The impact of state safe routes to school-related laws on active travel to school policies and practices in US elementary schools. Health Place 18, 8-15 (2012)

Cook, H.: School bus subsidy cut. The Age. http://www.theage.com.au/victoria/school-bus-subsidy-cut20121030-28hr2.html (2012)

Dellinger, A.M., Staunton, C.E.: Barriers to children walking and biking to school—United States, 1999. MMWR Morb. Mortal. Wkl. Rep. 51, 701-704 (2002)

Delucchi, M.: Motor-vehicle infrastructure and services provided by the public sector. Institute of Transportation Studies, Davis, CA (2005)

DiMaggio, C., Li, G.: Effectiveness of a safe routes to school program in preventing school-aged pedestrian injury. Pediatrics 131, 290-296 (2013). doi:10.1542/peds.2012-2182

Federal Highway Administration.: 2009 National household travel survey user's guide. U.S. Department of Transportation, Washington, DC (2011)

Federal Highway Administration.: Federal highway cost allocation study, final report. US Department of Transportation, Washington, DC (1997)

Federal Highway Administration.: Online analysis tools: table designer. US Department of Transportation. http://nhts.ornl.gov/tools.shtml (2014). Accessed 12 Nov 2014

Florida Department of Education.: The quality link: Florida school district transportation profiles. Florida Department of Education, Tallahassee, FL (2013)

Jarrett, J., Woodcock, J., Griffiths, U.K., Chalabi, Z., Edwards, P., Roberts, I., Haines, A.: Effect of increasing active travel in urban England and Wales on costs to the National Health Service. The Lancet 379, 2198-2205 (2012). doi:10.1016/S0140-6736(12)60766-1 
Larouche, R., Saunders, T.J., Faulkner, G.E.J., Colley, R., Tremblay, M.: Associations between active school transport and physical activity, body composition and cardiovascular fitness: a systematic review of 68 studies. J. Phys. Act. Health. 11, 206-227 (2014)

Litman, T., Doherty, E.: Transportation cost and benefit analysis: techniques, estimates and implications. Victoria Transport Policy Institute, Victoria, BC (2009)

McDonald, N.C., Aalborg, A.: Why parents drive children to school: implications for safe routes to school programs. J. Am. Plann. Assoc. 75, 331-342 (2009)

McDonald, N.C., Brown, A.L., Marchetti, L.M., Pedroso, M.S.: U.S. school travel 2009: an assessment of trends. Am. J. Prev. Med. 41, 146-151 (2011)

McDonald, N.C., Howlett, M.A.: Funding for pupil transportation: framework for analysis. Transp. Res. Rec. 2009, 98-103 (2007)

McDonald, N.C., Steiner, R.L., Lee, C., Smith, T.R., Zhu, X., Yang, Y.: Impact of the safe routes to school program on walking and bicycling. J. Am. Plann. Assoc. 80.(2014) doi:10.1080/01944363.2014. 956654

McMillan, T.: The relative influence of urban form on a child's travel mode to school. Transp. Res. A 41, 69-79 (2007)

Moore, M.A., Boardman, A.E., Vining, A.R., Weimer, D.L., Greenberg, D.H.: Just give me a number! Practical values for the social discount rate. J. Policy Anal. Manage. 23, 789-812 (2004)

National Center for Education Statistics.: Table 37: enrollment in public elementary and secondary schools: fall 2010. US Department of Education. http://nces.ed.gov/programs/digest/d12/tables/dt12_037.asp (2012). Accessed 12 Nov 2014

National Center for Safe Routes to School.: Shifting modes: a comparative analysis of safe routes to school program elements and travel mode outcomes. National Center for Safe Routes to School, Chapel Hill, $\mathrm{NC}(2012)$

Ogden, C.L., Carroll, M.D., Kit, B.K., Flegal, K.M.: Prevalence of childhood and adult obesity in the United States, 2011-12. JAMA 311, 806-814 (2014). doi:10.1001/jama.2014.732

Parisi Associates (n.d.) Transportation tools to improve children's health and mobility: look what California is doing. California Department of Transportation, Sacramento, CA. http://www.dot.ca.gov/hq/ LocalPrograms/TransportationToolsforSR2S.pdf. Accessed 12 Nov 2014

Pedroso, M.S., Hubsmith, D., Driesse, B.: Safe routes to school: helping communities save lives and dollars. Safe Routes to School National Partnership, Washington, DC (2011)

Pullen-Seufert, N., Marchetti, L.M., Brown, A.L., LaJeunesse, S.: Walking and bicycling in the USA: the status and future of safe routes to school in the USA. National Center for Safe Routes to School, Chapel Hill, NC (2009)

Ragland, D.R., Pande, S., Bigham, J., Cooper, J.F.: Ten years later: examining the long-term impact of the California Safe Routes to School program. Transportation Research Board 93rd annual meeting, Washington, DC (2014)

Safe Routes to School National Partnership.: Buses, boots, and bicycles: exploring collaboration between safe routes to school and school busing professionals to get children to school safely and healthily. Safe Routes to School National Partnership, Washington, DC (2014)

Safe Routes to School National Partnership.: Local success stories: reducing bus transportation costs. http:// www.saferoutespartnership.org/local/local-success-stories\#ReducingBusCosts (2010). Accessed 28 Feb 2014

Sisiopiku, V.P., Ramadan, O., McDonald, N.C.: Development of a cost breakdown structure for quantifying school transportation costs for various modes. Eur. Int. J. Sci. Technol. 2, 235-250 (2013)

Staunton, C.E., Hubsmith, D., Kallins, W.: Promoting safe walking and biking to school: the Marin County success story. Am. J. Public Health 93, 1431-1434 (2003)

Stewart, O., Moudon, A.V., Claybrooke, C.: Multistate evaluation of Safe Routes to School programs. Am. J. Health Promot. 28, S89-S96 (2014)

Trottenberg, P.: Revised departmental guidance on valuation of travel time in economic analysis. US Department of Transportation, Washington, DC (2011)

U.S. Department of Education, National Center for Education Statistics.: Table 2: current expenditures for public elementary and secondary education, by function, subfunction, and state or jurisdiction: school year 2010-11. http://nces.ed.gov/pubs2013/expenditures2/tables/table_02.asp (2013). Accessed 12 Nov 2014

van Ristell, J.A., Quddus, M.A., Enoch, M.P., Wang, C., Hardy, P.: Quantifying the impacts of subsidy policies on home-to-school pupil travel by bus in England. Transportation. doi: 10.1007/s11116-0149525-6 (2014)

Zhu, X., Lee, C.: Correlates of walking to school and implications for public policies: survey results from parents of elementary school children in Austin, Texas. J. Public Health Policy 30, S177-S202 (2009) 
Noreen C. McDonald is an Associate Professor in the Department of City and Regional Planning at the University of North Carolina at Chapel Hill. Her research interests include travel behavior and infrastructure planning.

Ruth L. Steiner is a Professor in the Department of Urban and Regional Planning and Director of the Center for Health and the Built Environment at the University of Florida. Her research focuses on the coordination of land use and transportation and its impact on communities, health and the environment.

W. Mathew Palmer is a Doctoral Student in the Department of City and Regional Planning at the University of North Carolina at Chapel Hill. His research interests include school travel behavior and educational facility planning.

Allison N. Bullock is a Planner at Alta Planning + Design, where she specializes in bicycle, pedestrian, and complete streets planning. She received a Master's in City and Regional Planning from the University of North Carolina at Chapel Hill in May 2013.

Virginia P. Sisiopiku is an Associate Professor in the Department of Civil, Construction, and Environmental Engineering at the University of Alabama at Birmingham. Her research interests include traffic operations and safety and sustainable transportation.

Benjamin F. Lytle is a planner in the Orlando office of AECOM. He received a Master of Arts in Urban and Regional Planning from the University of Florida in August 2014. 